\title{
Gold-catalyzed formation of pyrrolo- and indolo-oxazin-1-one derivatives: The key structure of some marine natural products
}

\author{
Sultan Taskaya ${ }^{1}$, Nurettin Menges ${ }^{* 1,2}$ and Metin Balci ${ }^{* 1}$
}

\author{
Full Research Paper \\ Address: \\ ${ }^{1}$ Middle East Technical University, Department of Chemistry, Ankara, \\ Turkey, 06800 and ${ }^{2}$ Yüzüncü Yil University, Faculty of Pharmacy, \\ Van, Turkey, 65100

\section{Email:} \\ Nurettin Menges ${ }^{*}$ - nurettinmenges@gmail.com; \\ Metin Balci* - mbalci@metu.edu.tr \\ * Corresponding author \\ Keywords: \\ alkyne cyclization; gold-catalyzed reaction; indolo-oxazin-1-one; \\ marine natural products; pyrrolo-oxazin-1-one
}

\author{
Beilstein J. Org. Chem. 2015, 11, 897-905. \\ doi:10.3762/bjoc.11.101 \\ Received: 10 February 2015 \\ Accepted: 24 April 2015 \\ Published: 28 May 2015 \\ Associate Editor: J. P. Wolfe \\ (C) 2015 Taskaya et al; licensee Beilstein-Institut. \\ License and terms: see end of document.
}

\begin{abstract}
Various $N$-propargylpyrrole and indolecarboxylic acids were efficiently converted into 3,4-dihydropyrrolo- and indolo-oxazin-1one derivatives by a gold(III)-catalyzed cyclization reaction. Some of the products underwent TFA-catalyzed double bond isomerization and some did not. Cyclization reactions in the presence of alcohol catalyzed by $\mathrm{Au}(\mathrm{I})$ resulted in the formation of hemiacetals after cascade reactions.
\end{abstract}

\section{Introduction}

Pyrrole-containing heterocycles are widely distributed within a large number of natural products and biologically active molecules [1]. These compounds possess a wide range of biological and pharmacological activities [2-5]. The oxazinone moiety is also frequently found in compounds displaying biological activities [6,7]. Pyrrolo-oxazinone structures with an oxazinone ring fused to a pyrrole are found in marine natural products, such as lukianol A (1) and lukianol B (2) (Figure 1) [8-10]. Lukianol B (2) was found to be the most potent human aldose reductase (h-ALR2) inhibitor in thousands of marine natural products screened [11]. The ningalin B alkaloid 3, having an isomeric pyrrolo-oxazinone skeleton, possesses antitumor and multidrug resistance reversal activity [12-14]. Lamellarins 4 with a pyrrolo-oxazinone substructure are also marine natural products and they inhibit the proliferation of cancer cells and therefore are promising candidates for anticancer drugs [15-20].

The design and synthesis of pharmaceutically relevant building blocks has always been a significant goal in organic synthesis. Moreover, modification of natural products is also an important approach to identify promising anticancer agents. Especially due to the bioactivity of lukianols, many groups accomplished the synthesis of these marine products and their analogues [2126]. Despite the general and widespread interest in these struc- 


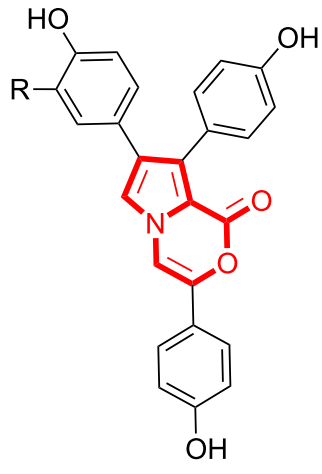

1 Lukianol A (R:H)

2 Lukianol B (R:I)<smiles>O=c1oc2cc(O)c(O)cc2c2c(-c3ccc(O)c(O)c3)cn(CCc3ccc(O)c(O)c3)c12</smiles>

3 Ningalin B<smiles>COc1cc(-c2c3n(c4c(=O)oc5cc(O)c(O)cc5c24)C(O)Cc2c-3cc(OC)c(OC)c2OC)ccc1O</smiles>

4 Lamellarin A

Figure 1: Structures of some marine natural products 1-4.

tures, the core structure, $1 H$-pyrrolo[2,1-c][1,4]oxazin-1-one (5), is not described in the literature. However, there are relatively few synthetic routes leading to the substituted core structure 6 (Figure 2), which was generated by treatment of methyl 2-pyrrole-carboxylate with chloroacetone [2,27-30]. This core structure is also a very important intermediate for the synthesis of pyrrolo-pyrazinones as well as for pyrrolo-pyrazines [31]. Recently, Wang et al. reported the base-catalyzed intramolecular cyclization of alkynyl alcohols at high temperatures to give 1,4-oxaza heterocycles [32].

$$
\underbrace{1}_{0}
$$

5

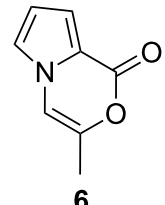

6

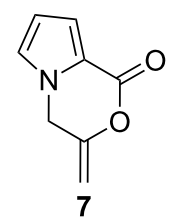

Figure 2: Structures 5-7.

In this manuscript we envisaged a synthetic strategy leading to the core skeleton of marine products $\mathbf{6}$ and $\mathbf{7}$ (Figure 2) or their analogues with short reaction times and an atom-economic process using a gold-catalyzed alkyne cyclization reaction as the key step.
Pyrrole and indole, bearing one (substituted) propargyl and carboxy group was initially designed as model substrate for the construction of $\mathbf{6}$ and 7. Gold-catalyzed intramolecular cyclization of enyene carboxylic acids has been reported in the literature to give the corresponding lactones [33-40]. For example, gold(I)-catalyzed reaction of 2-(phenylethynyl)benzoic acid (8) yielded the exo- and endo-dig cyclization products, lactones 9 and $\mathbf{1 0}$ in $62 \%$ yield in a ratio of 6:1 (Scheme 1) [41].

\section{Results and Discussion}

The starting compound $\mathbf{1 1}$ was synthesized via a slightly modified route by acetylation of pyrrole with trichloroacetyl chloride in $99 \%$ yield $[42,43]$. The propargyl ester 13 [44-46] was obtained in high yield from the reaction of $\mathbf{1 2}$ with propargyl bromide in the presence of $\mathrm{NaH}$ as a base (Scheme 2). Gold catalysis is an excellent method for constructing complex chemical architectures in a mild manner that would be difficult to achieve using other reactions [41,47-53]. Reaction of propargyl ester 13 with $\mathrm{AuCl}_{3}$ resulted in the formation of 14, which is an $\mathrm{H}_{2} \mathrm{O}$ (present in the reaction media) addition product to alkyne units. It has been proposed that a gold-activated water intermediate can easily be added to alkynes. The addition of water to alkyne has been reported by several research groups [54,55]. The expected cyclization product having the structure 6 or 7 was not formed.<smiles>O=C(O)c1ccccc1C#Cc1ccccc1</smiles>
$\mathrm{CH}_{3} \mathrm{CN}, \mathrm{rt}, 62 \%$

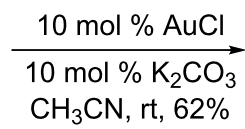<smiles>O=C1O/C(=C\c2ccccc2)c2ccccc21</smiles><smiles>O=c1oc(-c2ccccc2)cc2ccccc12</smiles>

$(6: 1)$ 

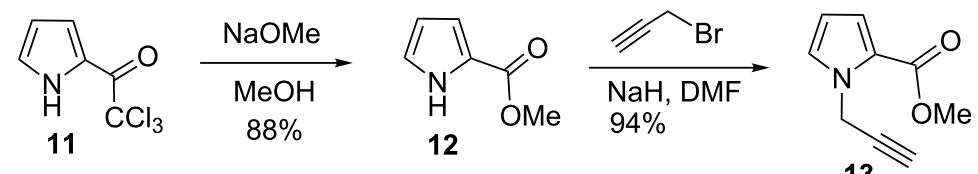

13

$\mathrm{AuCl}_{3}, 10 \%$

$\mathrm{CHCl}_{3}, 25^{\circ} \mathrm{C}$

$\left(\mathrm{H}_{2} \mathrm{O}\right)$

not observed<smiles>COC(=O)c1cccn1CC(C)=O</smiles>

Scheme 2: Synthesis of 13 and its reaction with $\mathrm{AuCl}_{3}$.

After failure of the cyclization reaction of 13 with $\mathrm{AuCl}_{3}$, even in water-free solvents, we turned our attention to the construction of the pyrrolo-oxazin-1-one skeleton with the corresponding acid 15. For this purpose, the propargyl ester $\mathbf{1 3}$ was first hydrolyzed with $\mathrm{K}_{2} \mathrm{CO}_{3}$ to acid 15 (Scheme 3) [56]. The acid 15 was reacted with various metal catalysts in chloroform at different temperatures and for different reaction times. Five different catalysts were tried (Table 1). Surprisingly, no reaction was observed when the reaction was conducted with the $\mathrm{N}$-heterocyclic carbene (NHC) complex of $\mathrm{Au}(\mathrm{I})$ in chloroform (Table 1, entry 5). Reactions with $\mathrm{InCl}_{3}$ and $\mathrm{PtCl}_{2}\left(\mathrm{PPh}_{3}\right)_{3}$ as catalysts gave very poor yields of exo-dig cyclization product 7 after $24 \mathrm{~h}$ (entries 3 and 4). AgOTf and $\mathrm{AuCl}_{3}$ were also screened and $\mathrm{AuCl}_{3}$ was identified as the optimal choice due to the shorter reaction time, high yield, and easy isolation of the product 7 (entries 1 and 2, Table 1). We next investigated the isomerization of the double bond in 7 , which was treated with trifluoroacetic acid (TFA) in chloroform at room temperature to give 3-methyl-1H-pyrrolo[2,1-c][1,4] oxazin-1-one (6) [27].

After having obtained the optimal conditions for the Au-catalyzed cyclization of carboxylic acid 15, we attempted to determine the scope and limitation of this transformation. Then we investigated the cyclization reaction of a range of substituted $N$-propargyl-pyrrole-2-carboxylic acids 17, 21, 25, 29 and

\begin{tabular}{clccc} 
Table 1: Optimization of cyclization reaction of $\mathbf{1 5}$ & \\
Entry & Catalyst & $\begin{array}{c}\text { Time } \\
(\mathrm{h})\end{array}$ & $\begin{array}{c}\text { Temperature } \\
\left({ }^{\circ} \mathrm{C}\right)\end{array}$ & $\begin{array}{c}\text { Yield } \\
(\%)\end{array}$ \\
\hline 1 & $\mathrm{AuCl}_{3}$ & 2 & $\mathrm{rt}$ & 96 \\
2 & $\mathrm{AgOTf}_{3}$ & 20 & $\mathrm{rt}$ & 95 \\
4 & $\mathrm{InCl}_{3}$ & 24 & 50 & 13 \\
4 & $\mathrm{PtCl}_{2}(\mathrm{PPh})_{3}$ & 26 & 50 & 5 \\
5 & $\mathrm{Au}(\mathrm{L})^{\mathrm{a}}$ & 24 & $\mathrm{rt}$ & $\begin{array}{c}\text { No } \\
\text { reaction }\end{array}$
\end{tabular}

a<smiles>CC(C)c1cccc(C(C)C)c1N1C=CN(c2c(C(C)C)cccc2C(C)C)C1=[Ge]Cl</smiles>

$\mathrm{Au}(\mathrm{L})$

33 and $N$-propargylindole-2-carboxylic acids 37, 41 and 45, which were synthesized by hydrolysis of the corresponding esters (Table 2). The Sonogashira cross-coupling reaction [5661] was used for the synthesis of the desired starting materials 29 and 33. For the Sonogashira coupling reaction we used a palladium catalyst and a copper(I) cocatalyst in the presence of triphenylphosphine and triethylamine as the base. The<smiles>C#CCn1cccc1C(=O)OC</smiles>

13

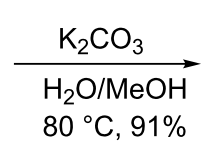

$80^{\circ} \mathrm{C}, 91 \%$<smiles>C#CCn1cccc1C(=O)O</smiles>

catalyst, $3 \%$

$\mathrm{CHCl}_{3}, 96 \%$

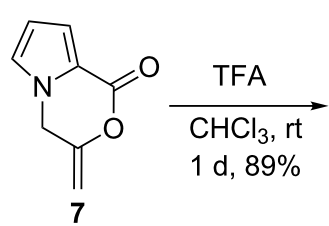<smiles>Cc1cn2cccc2c(=O)o1</smiles> 
carboxylic acids were then submitted to a gold-catalyzed cyclization reaction (Table 2).

The optimized reaction conditions for cyclization was employed for pyrrole- and indole-carboxylic acids. We observed that all substituted pyrrole as well as indole carboxylic acids underwent a smooth gold-catalyzed cyclization reaction to afford the corresponding oxazinones 18, 22, 26, 30, 34, 38, 42 and 46 in high yields (Table 2). Substitution at the terminal carbon atom of the propargyl group with methyl and phenyl groups did not affect the mode of the cyclization reaction.

Further investigation of cyclic products involved examining the isomerization of the exocyclic double bond. For this purpose,

Table 2: $\mathrm{AuCl}_{3}$-catalyzed cyclization reaction of carboxylic acids.<smiles>[R]c1c(C(=O)OC)n(CC#C)c2ccccc12</smiles>

A<smiles>[R]c1c(C(=O)O)n(CC#C)c2ccccc12</smiles>

B

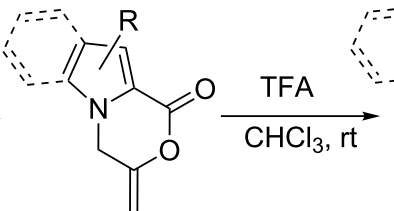

C<smiles>[R]c1ccccc1-n1cc(C)oc(=O)c1=O</smiles>

D

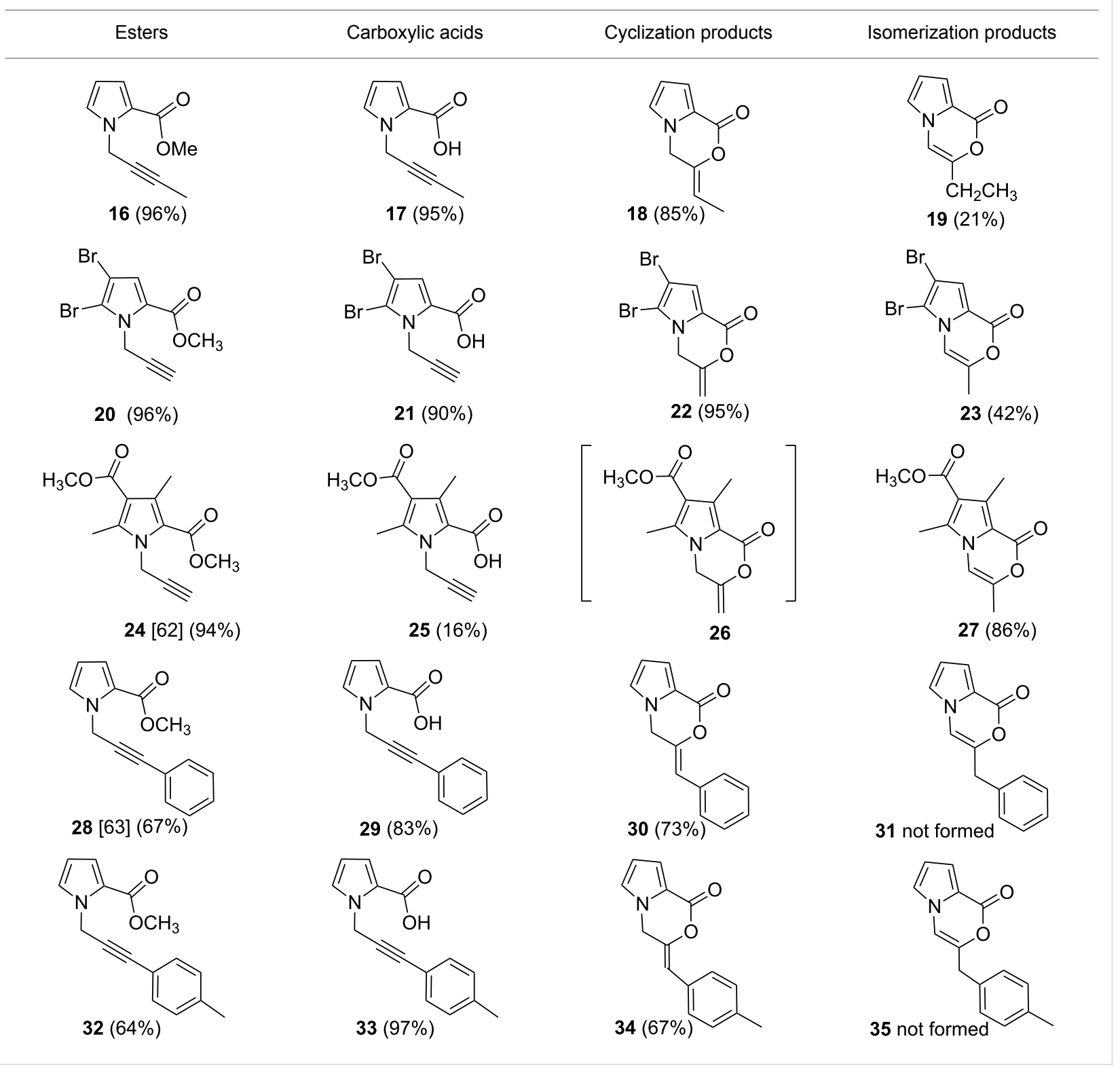


Table 2: $\mathrm{AuCl}_{3}$-catalyzed cyclization reaction of carboxylic acids. (continued)<smiles>C#CCn1c(C(=O)OCC)cc2ccccc21</smiles>

36 [64] (98\%)<smiles>CC#CCn1c(C(=O)OCC)cc2ccccc21</smiles><smiles>[Te][Te]</smiles><smiles>C#CCn1c(C(=O)OCC)c(C=O)c2ccccc21</smiles>

$44(72 \%)$<smiles>C#CCn1c(C(=O)O)cc2ccccc21</smiles>

37 [65] (97\%)<smiles>CC#CCn1c(C(=O)O)cc2ccccc21</smiles>

$41(97 \%)$<smiles>C#CCn1c(C(=O)O)c(C=O)c2ccccc21</smiles><smiles>C=C1Cn2c(cc3ccccc32)C(=O)O1</smiles>

38 (99\%)<smiles>C/C=C1/Cn2c(cc3ccccc32)C(=O)O1</smiles>

$42(96 \%)$<smiles>C=C1Cn2c(c(C=O)c3ccccc32)C(=O)O1</smiles>

$46(92 \%)$<smiles>Cc1cn2c(cc3ccccc32)c(=O)o1</smiles>

$39(83 \%)$<smiles>CCc1cn2c(cc3ccccc32)c(=O)o1</smiles>

Decomposition the cyclization products were reacted with trifloroacetic acid (TFA) to form endo-cyclic double bonds. Some of the compounds underwent double bond shifts to form an oxazinone skeleton 19, 23, 27, 39 and 43, whereas the compounds 30 and 34 did not form the corresponding endo-cyclic systems $\mathbf{3 1}$ and 35. In order to address this question, we carried out some DFT calculations [66].

The calculations performed in the gase phase showed that 6 is about $10.6 \mathrm{kcal} / \mathrm{mol}$ (DFT, B3LYP at $6-31 \mathrm{G}^{* *}$ level) and $8.1 \mathrm{kcal} / \mathrm{mol}(\mathrm{HF} / 6-311 \mathrm{G} * *$ level) more stable than 7 (Figure 3). However, in the case of $\mathbf{3 0}$ and $\mathbf{3 1}$, we also found that the endo-cyclic isomer $\mathbf{3 1}$ is thermodynamically about $4.8 \mathrm{kcal} / \mathrm{mol}$ (DFT, B3LYP at $6-31 \mathrm{G}^{* *}$ level) and $3.8 \mathrm{kcal} / \mathrm{mol}$ $\left(\mathrm{HF} / 6-311 \mathrm{G}^{* *}\right.$ level) more stable than the exo-cyclic isomer 30.
Although $\mathbf{3 1}$ is thermodynamically more stable than $\mathbf{3 0}$, the resistance of $\mathbf{3 0}$ to isomerization in the presence of TFA can be explained by the regioselective protonation of the double bond. The proton is added to the carbon atom to generate the most stable carbocation. The most stable carbocation is the benzylic carbocation which would not undergo a rearrangement.

As discussed above, when the cyclization reaction of $\mathbf{1 5}$ was carried out with [(NHC)AuCl] complexes (Table 1, entry 5), the starting material was fully recovered. Gold $N$-heterocyclic carbene complexes, in conjunction with a silver salt, were found to efficiently catalyze different types of reactions [67-69]. Therefore, 15 was reacted with [(NHC)AuCl] complex in the presence of AgOTf as the cocatalyst in chloroform. Beside the expected cyclization product $7(10 \%)$, the product 47 was

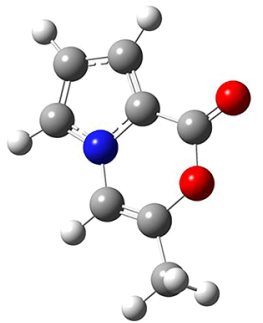

6

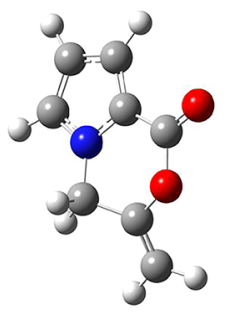

7

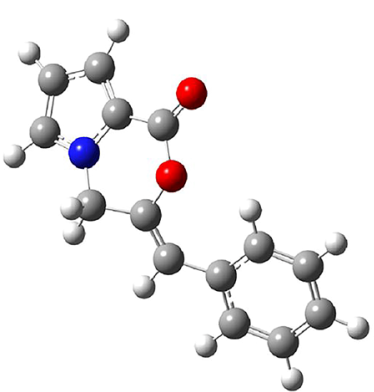

30

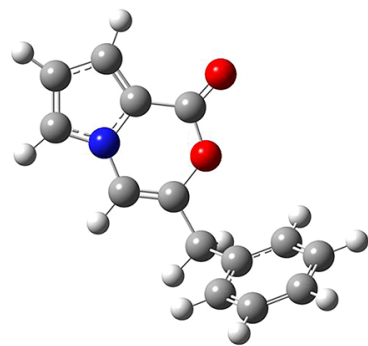

31

Figure 3: Geometry optimized structures of 6, 7, 30 and 31. 
formed conclusively through incorporation of ethanol present in chloroform $(<1 \%)$ as the major product in $51 \%$ yield (Scheme 4). NMR spectral analysis of the mixture revealed also the formation of $\mathbf{4 8}$ in 39\% yield, which is the hydrolysis product of 47. Attempts to isolate $\mathbf{4 7}$ failed. Chromatography on silica gel converted 47 to 48 in almost quantitative yield. However, the products $\mathbf{6}$ and $\mathbf{7}$ only were isolated when the reaction was carried out in EtOH-free chloroform in $83 \%$ and $17 \%$ yields, respectively (Scheme 4 ).

To reveal the mechanism for the formation of the products we carried out two different reactions. First, 15 was reacted with $\mathrm{CD}_{3} \mathrm{OD}$ under the same reaction conditions. The ${ }^{1} \mathrm{H}$ NMR spectral analysis indicated the formation of 49 and $\mathbf{5 0}$ in $65 \%$ and $35 \%$ yields, respectively. Furthermore, the amount of deuterium atoms in $\mathbf{4 9}$ and $\mathbf{5 0}$ attached to the methylene group as $-\mathrm{CH}_{2} \mathrm{D}$ was about $64 \%$ (Scheme 4 ).

To prove whether 7 was involved as the intermediate, the cyclization product 7 was reacted with $\mathrm{Au}(\mathrm{I}) / \mathrm{AgOTf}$ with $\mathrm{EtOH}$ under the same reaction conditions. As a result, the products 47 and 48 were formed in yields of $39 \%$ and $61 \%$, respectively (Scheme 5).

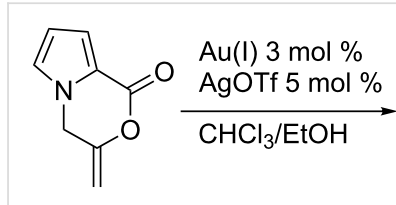

7<smiles>CCOC1(C)Cn2cccc2C(=O)O1</smiles>

$47(39 \%)$<smiles>CC(=O)Cn1cccc1C(=O)O</smiles>

$48(61 \%)$
Scheme 5: Reaction of 7 with $\mathrm{Au}(\mathrm{I}) / \mathrm{AgOTf}$ in the presence of $\mathrm{EtOH}$.

Based on all this information obtained, we propose the following gold-catalyzed cascade reaction mechanism. The proposed catalytic cycle was initiated with $\pi$-activation of the triple bond by the carbene-based cationic gold species to form the intermediate 51, which triggers a gold-promoted intramolecular addition of a carboxy group to the alkyne functionality to give methylene-oxazin-1-one derivative 7 (or 18) (Scheme 6). In the next step, the double bond is activated by $\pi$-coordination of the gold(I) catalyst. This enables a nucleophilic attack by the<smiles>[3H][Te]/C=C1/Cn2cccc2C(=O)O1</smiles>
$\mathrm{Au}(\mathrm{I}) 3 \mathrm{~mol} \%$
$\mathrm{AgOTf} 5 \mathrm{~mol} \%$
dry $\mathrm{CHCl}_{3}$<smiles>C#CCn1cccc1C(=O)O</smiles>

15
$\mathrm{Au}(\mathrm{I}) 3 \mathrm{~mol} \%$

$\underset{\mathrm{CHCl}_{3},(\mathrm{EtOH})}{\stackrel{\mathrm{AgOTf}}{\mathrm{Cmol} \%}}$

$\mathrm{Au}(\mathrm{I}) 3 \mathrm{~mol} \%$ AgOTf $5 \mathrm{~mol} \%$ $\mathrm{CD}_{3} \mathrm{OD}$ (2 equiv)

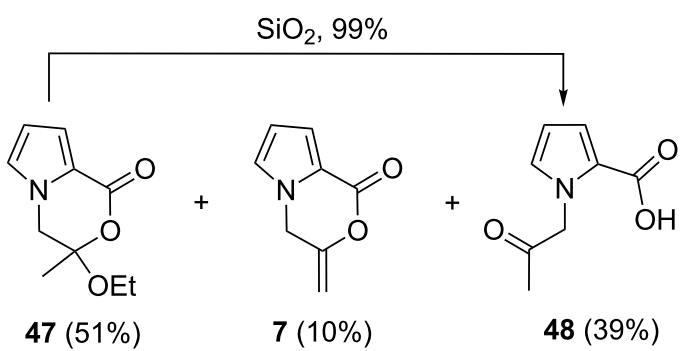<smiles>[R]C[C@]1(O[Na])Cn2cccc2C(=O)O1</smiles> 


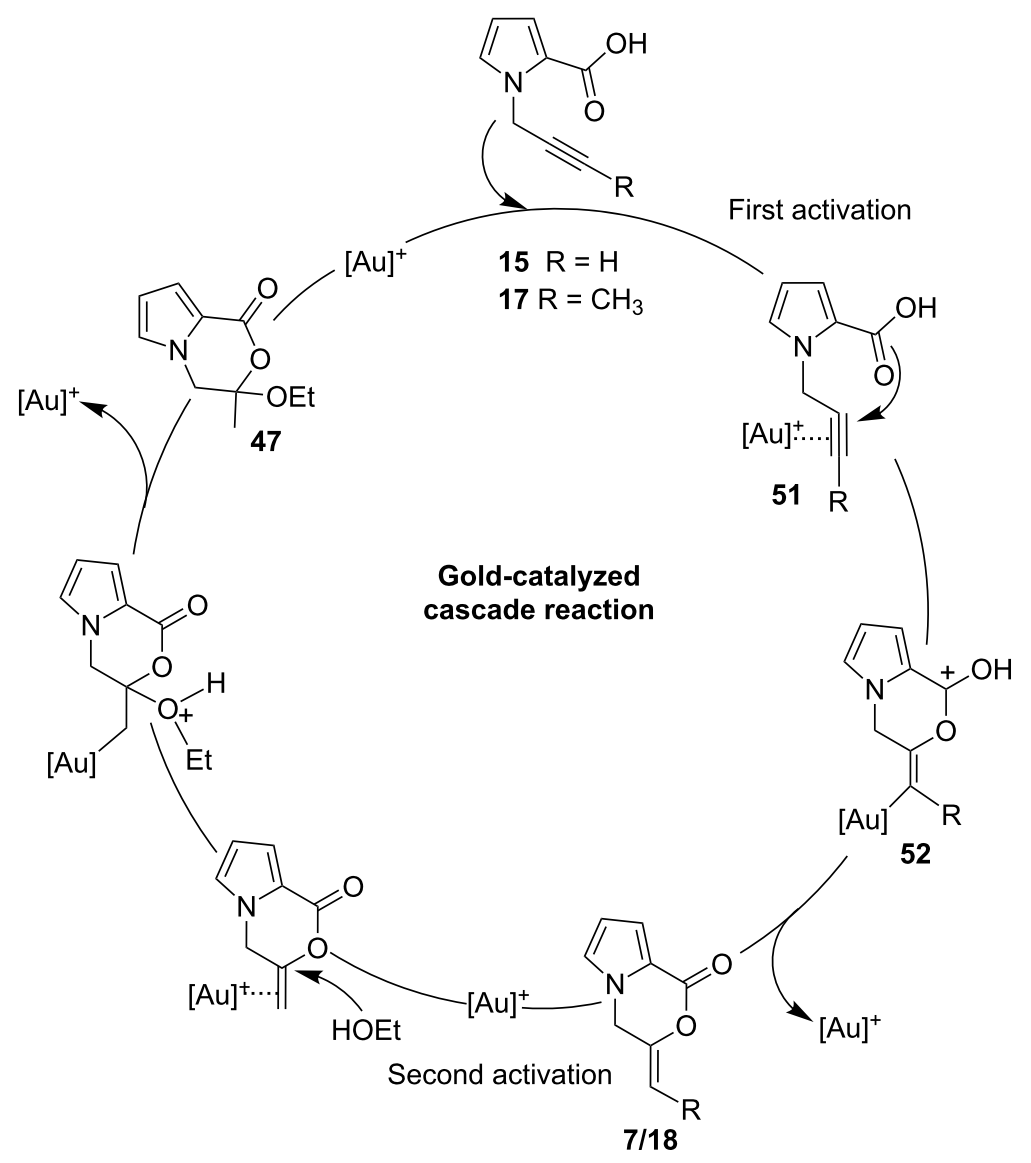

Scheme 6: Proposed reaction mechanism for the intramolecular gold-catalyzed cyclization followed by EtOH addition.

alcohol oxygen, which affords hemiacetal 47. In case of internal alkynes, two isomeric $E$ - and $Z$-oxazinones during the cyclization reaction can be formed. However, we observed exclusive formation of a single isomer. Recently, Michelet et al. [70] and others $[41,71,72]$ demonstrated selectively the formation of $Z$-lactones. The anti intramolecular addition of the carboxylic acid to the gold-alkyne intermediate $\mathbf{5 1}$, forms an intermediate 52 where the substituent is in the endo-position. Removal of gold results in the formation of $Z$-isomer. Therefore, we assign the endo-configuration to the formed oxazinones.

\section{Conclusion}

We have developed a general synthetic methodology of pyrroloand indolo-oxazin-1-one derivatives. The key step was a goldcatalyzed cyclization reaction of N-propargyl-substituted pyrrole and indole carboxylic acid derivatives. The hydroxy groups of carboxylic acids attacked the activated triple bond to form 6-exo-dig cyclization products, oxazin-1-one derivatives. Some of the exo-cyclic double bonds underwent isomerization to endo-cyclic compounds upon treatment with TFA, while some did not. DFT studies supported our findings. Moreover, cyclization reactions in the presence of alcohol formed hemiacetal derivatives after gold-catalyzed cascade reactions.

\section{Supporting Information}

\section{Supporting Information File 1}

Experimental and analytical data.

[http://www.beilstein-journals.org/bjoc/content/ supplementary/1860-5397-11-101-S1.pdf]

\section{Supporting Information File 2 NMR spectra.}

[http://www.beilstein-journals.org/bjoc/content/ supplementary/1860-5397-11-101-S2.pdf]

\section{Acknowledgements}

Financial support from the Scientific and Technological Research Council of Turkey (TUBITAK, Grant No. TBAG-112 T360), the Turkish Academy of Sciences (TUBA), and Middle East Technical University (METU) is gratefully acknowledged. 


\section{References}

1. Gossauer, A. Pyrrole. Houben-Weyl-Methods of Organic Chemistry; Thieme: Stuttgart, 1994; Vol. E6a/1, pp $556 \mathrm{ff}$. See for a review.

2. Meng, Y.; Wang, G.; Li, Y.; Hou, K.; Yuan, Y.; Zhang, L.-J.; Song, H.-R.; Shi, W. Chin. Chem. Lett. 2013, 24, 619-621. doi:10.1016/j.cclet.2013.04.020

3. Han, S.; Siegel, D. S.; Morrison, K. C.; Hergenrother, P. J.; Movassaghi, M. J. Org. Chem. 2013, 78, 11970-11984. doi:10.1021/jo4020112

4. Krishnaiah, P.; Reddy, V. L. N.; Venkataramana, G.; Ravinder, K.; Srinivasulu, M.; Raju, T. V.; Ravikumar, K.; Chandrasekar, D.; Ramakrishna, S.; Venkateswarlu, Y. J. Nat. Prod. 2004, 67, 1168-1171. doi:10.1021/np030503t

5. Rochais, C.; Lisowski, V.; Dallemagne, P.; Rault, S. Bioorg. Med. Chem. 2006, 14, 8162-8175. doi:10.1016/j.bmc.2006.09.022

6. Benaamane, N.; Nedjar-Kolli, B.; Bentarzi, Y.; Hammal, L.; Geronikaki, A.; Eleftheriou, P.; Lagunin, A. Bioorg. Med. Chem. 2008, 16, 3059-3066. doi:10.1016/j.bmc.2007.12.033

7. Kern, J. C.; Terefenko, E. A.; Fensome, A.; Unwallla, R.; Wrobel, J.; Zhu, Y.; Cohen, J.; Winneker, R.; Zhang, Z.; Zhang, P. Bioorg. Med. Chem. Lett. 2007, 17, 189-192. doi:10.1016/j.bmcl.2006.09.060

8. Yoshida, W. Y.; Lee, K. K.; Carrol, A. R.; Scheuer, P. J. Helv. Chim. Acta 1992, 75, 1721-1725. doi:10.1002/hlca.19920750525

9. Lu, Y.; Arndtsen, B. A. Org. Lett. 2009, 11, 1369-1372. doi:10.1021/ol900185n

10. Takamura, K.; Matsuo, H.; Tanaka, A.; Tanaka, J.; Fukuda, T.; Ishibashi, F.; Iwao, M. Tetrahedron 2013, 69, 2782-2788. doi:10.1016/j.tet.2013.01.077

11. Manzanaro, S.; Salvá, J.; de la Fuente, J. Á. J. Nat. Prod. 2006, 69 1485-1487. doi:10.1021/np0503698

12. Kang, H.; Fenical, W. J. Org. Chem. 1997, 62, 3254-3262. doi:10.1021/jo962132+

13. Hasse, K.; Willis, A. C.; Banwell, M. G. Aust. J. Chem. 2009, 62, 683-691. doi:10.1071/CH09158

14. Li, Q.; Jiang, J.; Fan, A.; Cui, Y.; Jia, Y. Org. Lett. 2011, 13, 312-315. doi:10.1021/ol1027877

15. Andersen, R. J.; Faulkner, D. J.; Cun-heng, H.; Van Duyne, G. D.; Clardy, J. J. Am. Chem. Soc. 1985, 107, 5492-5495. doi:10.1021/ja00305a027

16. Carroll, A. R.; Bowden, B. F.; Coll, J. C. Aust. J. Chem. 1993, 46, 489-501. doi:10.1071/CH9930489

17. Urban, S.; Butler, M. S.; Capon, R. J. Aust. J. Chem. 1994, 47, 1919-1924. doi:10.1071/CH9941919

18. Fan, H.; Peng, J.; Hamann, M. T.; Hu, J.-F. Chem. Rev. 2008, 108, 264-287. doi:10.1021/cr078199m

19. Chittchang, M.; Paul, G. M.; Ploypradith, P.; Ruchirawat, S Eur. J. Med. Chem. 2010, 45, 2165-2172. doi:10.1016/j.ejmech.2010.01.053

20. Ueda, K.; Amaike, K.; Maceiczyk, R. M.; Itami, K.; Yamaguchi, J. J. Am. Chem. Soc. 2014, 136, 13226-13232. doi:10.1021/ja508449y

21. Mathew, P.; Asokan, C. W. Tetrahedron Lett. 2005, 46, 475-478. doi:10.1016/j.tetlet.2004.11.076

22. Fürstner, A.; Weintritt, H.; Hupperts, A. J. Org. Chem. 1995, 60, 6637-6641. doi:10.1021/jo00125a068

23. Boger, D. L.; Boyce, C. W.; Labroli, M. A.; Sehon, C. A.; Jin, Q. J. Am. Chem. Soc. 1999, 121, 54-62. doi:10.1021/ja982078+
24. Banwell, M. G.; Flynn, B. L.; Hamel, E.; Hockles, D. C. R. Chem. Commun. 1997, 207-208. doi:10.1039/a606793j

25. Hinze, C.; Kreipl, A.; Terpin, A.; Steglich, W. Synthesis 2007, 608-612. doi:10.1055/s-2007-965876

26. Peschko, C.; Winklhofer, C.; Terpin, A.; Steglich, W. Synthesis 2006, 3048-3057. doi:10.1055/s-2006-950191

27. Dumas, D. J. J. Org. Chem. 1988, 53, 4650-4653. doi:10.1021/jo00255a002

28. Khan, S. T.; Yu, P.; Hua, E.; Ali, S. N.; Nisa, M. Acta Crystallogr., Sect. E 2010, 66, o/711. doi:10.1107/S1600536810006951

29. Reddy, G. S.; Rajasekhar, K.; Praveen, C.; Mukkanti, K.; Reddy, P. P. Synth. Commun. 2008, 38, 3884-3893. doi:10.1080/00397910802238742

30. Vaillard, V. A.; Rossi, R. A.; Martín, S. E. Org. Biomol. Chem. 2011, 9, 4927-4935. doi:10.1039/c1ob05269a

31. Çetinkaya, Y.; Balci, M. Tetrahedron Lett. 2014, 55, 6698-6702. doi:10.1016/j.tetlet.2014.10.044

32. Vandavasi, J. K.; Hu, W.-P.; Senadi, G. C.; Boominathan, S. S. K.; Chen, H.-Y.; Wang, J.-J. Eur. J. Org. Chem. 2014, 6219-6226. doi:10.1002/ejoc.201402818

33. Hou, Q.; Zhang, Z.; Kong, F.; Wang, S.; Wang, H.; Yao, Z.-J. Chem. Commun. 2013, 49, 695-697. doi:10.1039/C2CC36245G

34. Hoffmann, M.; Miaskiewicz, S.; Weibel, J.-M.; Pale, P.; Blanc, A. Beilstein J. Org. Chem. 2013, 9, 1774-1780. doi:10.3762/bjoc.9.206

35. Seo, H.; Jun, M. E.; Egorova, O. A.; Lee, K.-H.; Kim, K.-T.; Ahn, K. H. Org. Lett. 2012, 14, 5062-5065. doi:10.1021/ol302291c

36. Yoshikawa, T.; Shindo, M. Org. Lett. 2009, 11, 5378-5381. doi:10.1021/ol902086t

37. Uchiyama, M.; Ozawa, H.; Takuma, K.; Matsumoto, Y.; Yonehara, M.; Hiroya, K.; Sakamoto, T. Org. Lett. 2006, 8, 5517-5520. doi:10.1021/ol062190+

38. Harkat, H.; Weibel, J.-M.; Pale, P. Tetrahedron Lett. 2006, 47, 6273-6276. doi:10.1016/j.tetlet.2006.06.129

39. Yao, T.; Larock, R. C. J. Org. Chem. 2003, 68, 5936-5942. doi:10.1021/jo034308v

40. Biagetti, M.; Bellina, F.; Carpita, A.; Stabile, P.; Rossi, R. Tetrahedron 2002, 58, 5023-5038. doi:10.1016/S0040-4020(02)00469-6

41. Marchal, E.; Uriac, P.; Legouin, B.; Toupet, L.; van de Weghe, P. Tetrahedron 2007, 63, 9979-9990. doi:10.1016/j.tet.2007.07.066

42. Hewlett, N. M.; Tepe, J. J. Org. Lett. 2011, 13, 4550-4553. doi:10.1021/ol201741r

43. Bailey, D. M.; Johnson, R. E.; Albertson, N. F. Org. Synth. 1971, 51, 100-102. doi:10.15227/orgsyn.051.0100

44. Menges, N.; Sari, O.; Abdullayev, Y.; Erdem, S. S.; Balci, M. J. Org. Chem. 2013, 78, 5184-5195. doi:10.1021/jo4001228

45. Nguyen, T. M.; Guzei, I. A.; Lee, D. J. Org. Chem. 2002, 67, 6553-6556. doi:10.1021/jo025630t

46. Nguyen, T. M.; Lee, D. Org. Lett. 2001, 3, 3161-3163. doi:10.1021/ol016462e

47. Blanco Jaimes, M. C.; Ahrens, A.; Pflästerer, D.; Rudolph, M.; Hashmi, A. S. K. Chem. - Eur. J. 2015, 21, 427-433. doi:10.1002/chem.201402524

48. Ueda, H.; Yamaguchi, M.; Kameya, H.; Sugimoto, K.; Tokuyama, H. Org. Lett. 2014, 16, 4948-4951. doi:10.1021/ol5024695

49. Sánchez-Larios, E.; Giacometti, R. D.; Hanessian, S. Eur. J. Org. Chem. 2014, 5664-5669. doi:10.1002/ejoc.201402803

50. Kim, C.; Kang, S.; Rhee, Y. H. J. Org. Chem. 2014, 79, 11119-11124. doi:10.1021/jo502103p 
51. Tokimizu, Y.; Oishi, S.; Fujii, N.; Ohno, H. Org. Lett. 2014, 16, 3138-3141. doi:10.1021/ol5012604

52. Vaidya, T.; Cheng, R.; Carlsen, P. N.; Frontier, A. J.; Eisenberg, R. Org. Lett. 2014, 16, 800-803. doi:10.1021/ol403542k

53. Hashmi, A. S. K. Acc. Chem. Res. 2014, 47, 864-876. doi:10.1021/ar500015k

54. Corma, A.; Ruiz, V. R.; Leyva-Pérez, A.; Sabater, M. J. Adv. Synth. Catal. 2010, 352, 1701-1710. doi:10.1002/adsc.201000094

55. Krauter, C. M.; Hashmi, A. S. K.; Pernpointner, M. ChemCatChem 2010, 2, 1226-1230. doi:10.1002/cctc. 201000136

56. Molteni, G. Heterocycles 2004, 63, 1423-1428. doi:10.3987/COM-04-10050

57. Chinchilla, R.; Nájera, C. Chem. Rev. 2007, 107, 874-922. doi:10.1021/cr050992x

58. Doucet, H.; Hierso, J.-C. Angew. Chem., Int. Ed. 2007, 46, 834-871. doi:10.1002/anie.200602761

59. Sonogashira, K.; Tohda, Y.; Hagihara, N. Tetrahedron Lett. 1975, 16, 4467-4470. doi:10.1016/S0040-4039(00)91094-3

60. Kost, A. N.; Grandberg, I. I. Adv. Heterocycl. Chem. 1966, 6, 347-429. doi:10.1016/S0065-2725(08)60579-6

61. Caporale, A.; Tartaggia, S.; Castellin, A.; de Lucchi, O. Beilstein J. Org. Chem. 2014, 10, 384-393. doi:10.3762/bjoc.10.36

62. Meng, G.; Zheng, M.-L.; Wang, M. Org. Prep. Proced. Int. 2011, 43, 308-311. doi:10.1080/00304948.2011.582005

63. Fumie, S. PCT Int. Appl. WO 9628250 A1, Sept 19, 1996; pp 232 ff.

64. Verniest, G.; Padwa, A. Org. Lett. 2008, 10, 4379-4382. doi:10.1021/ol801847j

65. Defossa, E.; Heinelt, U.; Klingler, O.; Zoller, G.; Al-Obeidi, F.; Walser, A.; Wildgoose, P.; Matter, H. Patent W 9933800 A1, July 8, 1999. (Chem. Abstr. 1999, 131, 87814).

66. Gaussian 09, Revision D.01; Gaussian, Inc.: Wallingford CT, 2009.

67. Wang, D.; Cai, R.; Sharma, S.; Jirak, J.; Thummanapelli, S. K.; Akhmedov, N. G.; Zhang, H.; Liu, X.; Petersen, J. L.; Shi, X. J. Am. Chem. Soc. 2012, 134, 9012-9019. doi:10.1021/ja303862z

68. Patrick, S. R.; Boogaerts, I. I. F.; Gaillard, S.; Slawin, A. M. Z.; Nolan, S. P. Beilstein J. Org. Chem. 2011, 7, 892-896. doi:10.3762/bjoc.7.102

69. Marion, N.; Ramón, R. S.; Nolan, S. P. J. Am. Chem. Soc. 2009, 131, 448-449. doi:10.1021/ja809403e

70. Genin, E.; Toullec, P. Y.; Antoniotti, S.; Brancour, C.; Genêt, J.-P.; Michelet, V. J. Am. Chem. Soc. 2006, 128, 3112-3113. doi:10.1021/ja056857j

71. Chernyak, N.; Gevorgyan, V. J. Am. Chem. Soc. 2008, 130, 5636-5637. doi:10.1021/ja8006534

72. Yamada, W.; Sugawara, Y.; Cheng, H. M.; Ikeno, T.; Yamada, T. Eur. J. Org. Chem. 2007, 2604-2607. doi:10.1002/ejoc.200700169

\section{License and Terms}

This is an Open Access article under the terms of the Creative Commons Attribution License

(http://creativecommons.org/licenses/by/2.0), which permits unrestricted use, distribution, and reproduction in any medium, provided the original work is properly cited.

The license is subject to the Beilstein Journal of Organic Chemistry terms and conditions:

(http://www.beilstein-journals.org/bjoc)

The definitive version of this article is the electronic one which can be found at:

doi:10.3762/bjoc. 11.101 